\title{
Surfaces
}

\section{"POST-POSTSTRUCTURALIST" OR PRELAPSARIAN? CULTURAL STUDIES AND THE NEW HISTORICISM}

\section{Patrick Brantlinger}

Volume 2, 1992

ACTES DU COLLOQUE « REPENSER LA CULTURE »

ACTS OF THE CONFERENCE "RETHINKING CULTURE"

URI : https://id.erudit.org/iderudit/1065223ar

DOI : https://doi.org/10.7202/1065223ar

Aller au sommaire du numéro

Éditeur(s)

Les Presses de l’Université de Montréal

ISSN

1188-2492 (imprimé)

1200-5320 (numérique)

Découvrir la revue

Citer ce document

Brantlinger, P. (1992). "POST-POSTSTRUCTURALIST" OR PRELAPSARIAN?

CULTURAL STUDIES AND THE NEW HISTORICISM. Surfaces, 2.

https://doi.org/10.7202/1065223ar
Résumé de l'article

Une comparaison entre le New Historicism et les Études Culturelles en tant qu'approches théoriques contemporaines du problème de l'analyse culturelle.
Copyright (c) Patrick Brantlinger, 1992

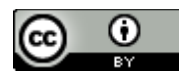

Ce document est protégé par la loi sur le droit d'auteur. L'utilisation des services d'Érudit (y compris la reproduction) est assujettie à sa politique d'utilisation que vous pouvez consulter en ligne.

https://apropos.erudit.org/fr/usagers/politique-dutilisation/ 
CONFERENCE PROCEEDINGS

"RETHINKING CULTURE"

"POST-POSTSTRUCTURALIST" OR PRELAPSARIAN?

CULTURAL STUDIES AND THE NEW HISTORICISM

Patrick Brantlinger

This paper was originally delivered at the conference

Rethinking Culture

held at the University of Montreal, April 3-5, 1992. The organizers would like to thank the following sponsors for their financial support:

Social Science Research Council of Canada

Faculty of Arts and Sciences, University of Montreal

Vice Rector for Teaching and Research, University of Montreal

Department of Comparative Literature, University of Montreal

Alitalia 
A comparison of New Historicism and Cultural Studies as contemporary theoretical approaches to the problem of cultural analysis.

\section{RÉSUMÉ}

Une comparaison entre le New Historicism et les Études Culturelles en tant qu'approches théoriques contemporaines du problème de l'analyse culturelle.

In his 1986 essay "What Is Cultural Studies Anyway?" Richard Johnson suggested that it might be a "post-post-structuralist" movement, and the same could be said of the New Historicism. [1] In a self-evident way, anything that comes after poststructuralism is either part of that phenomenon, from which it only slightly departs, or a new post-something, though it remains to ask whether this new post-something delivers the mail in such a completely new way as to displace, deconstruct, or even just somewhat disrupt the previous delivery system?[2] The "New" Historicism clearly promises novelty, though not in relation to poststructuralism -perhaps only in relation to an old historicism which, in most of its variants, equals Hegelian idealism, Whig liberalism, or Marxist materialism. Cultural Studies, too, does not always seem especially new or novel: it often blends Marxist ideological critique, of either an Althusserian or a Gramscian sort, with an ethnography of everyday life under capitalism, and it sometimes appears to be completely innocent of poststructuralism.

Rather than advances beyond poststructuralism, the New Historicism and Cultural Studies are best seen either as adaptations of it or escapes from its more radical implications. They also share many of the same assumptions and some of the same practitioners. Thus Alan Sinfield and Jonathan Dollimore -- the double editors of Political Shakespeare: New Essays on Cultural Materialism -- claim a dual allegiance. Their volume contains perhaps the most frequently cited example of New Historicist work, Stephen Greenblatt's "Invisible Bullets" essay, and it also contains an afterword by one of the founding fathers of British Cultural Studies, Raymond Williams. Similarly, when, in Learning to Curse, Greenblatt explains how he became a New Historicist, he points to the year he spent at Cambridge as a graduate student and the impact Williams's teaching made upon him. In place of Yale 
New Criticism, Williams offered a thoughtful version of Marxist literary and cultural analysis: "In Williams's lectures all that had been carefully excluded from the literary criticism in which I had been trained [at Yale] -- who controlled access to the printing press, who owned the land and the factories, whose voices were being repressed as well as represented in literary texts, what social strategies were being served by the aesthetic values we constructed -- came pressing back in upon the act of interpretation" (2).

Greenblatt's autobiographical sketch complicates the brief, critical comparison of the two movements offered by Robert Young in White Mythologies.[3] Writing about "the tactical use of Foucault...in current forms of criticism," Young spies a difference between the New Historicism and Cultural Studies: "The former is identified closely with Foucault, while the latter owes its allegiance to Raymond Williams, and really only amounts to a way of describing British ex-Marxists" (88). From a safe poststructuralist distance, Young rather contemptuously treats the similar desires of both movements to be politically efficacious as comical, Owl-of-Minerva-ish posturing in a post-Marxist void. His assertion that "the British cultural materialists quickly adopted a name which tactfully removes the suggestion of Marxism as such" (89) is matched, if not exactly balanced, by his claim that the cultural materialists are after all more common-sensical, more Foucauldian, and more effective about politics than "the more fastidious" and "more strictly academic new historicists, whose own politics remain more carefully hidden" (90).

Since one of Young's main targets is the old-style, orthodox Marxist metanarrative of history, he is inconsistent in criticizing perhaps ex- or perhaps post-Marxists for distancing themselves from that very metanarrative. Is post-Marxism less honorable in its postal politics than poststructuralism? Is it a sign of weak-kneed apostasy to arrive at Young's recognition that "Marxism's universalizing narrative of the unfolding of a rational system of world history is simply a negative form of the history of European imperialism" (Young 2)? Indeed, if the New Historicism is new, it is so largely through its claim to offer a version of "historicism" while challenging the teleological, imperializing assumptions of nineteenthcentury forms of historicism, and especially what Brook Thomas has called "narratives of progressive emergence," including both liberal and Marxist varieties.

Much of Greenblatt's work is anti-historicist at least in the sense that it is both anti-totalizing and anti-imperialist. Like "Invisible Bullets," most of the essays in both Learning to Curse and Marvelous Possessions open onto the terrain of cultural conflict and genocide that constitutes early American history. If Greenblatt's work can be taken as paradigmatic of the New Historicism as a whole, then that movement is partly an attack on the logocentric, ethnocentric tales called national histories that the European 
victors have told themselves throughout centuries of imperial domination of the rest of the world.[4] But on what grounds is the New Historicist attack made? Because the Marxist metanarrative of the past is just as Eurocentric as other versions of historicism, what allows for the narration of different, non-Eurocentric versions of the past? Greenblatt's replies to this question have led him from the literary-critical Marxism he learned from Williams, through what he used to call the New Historicism, to what he now calls "cultural poetics."

One virtue of such a formulation -- substituting "cultural poetics" for Marxism -- may lie in its acknowledgment that "there is nothing outside the text." But this virtue is just as readily understood as a problem. After poststructuralism, the only "materialism" possible seems to be a (merely?) discursive or cultural one. "Cultural poetics" is a tautological phrase -"culture" equals "poetics" -- that expresses the poststructuralist view that language can only refer to other language. It also represents a foreshortening of the old Marxist base/superstructure paradigm: the "material" or economic base has withered away; now there is only superstructure, culture, "poetics." What sorts of explanations can "cultural poetics" produce except poetic ones?

Lacking the explanatory power that referring cultural phenomena to the material or economic base once seemed to afford, "cultural poetics" appears to grant its practitioners complete license to reconstruct and retell any story about the past that they choose. Arbitrariness has been a charge leveled against the New Historicism from the beginning. Greenblatt himself is the first to concede that the New Historicism is not "systematic." As Catherine Gallagher also says, "The new historicist, unlike the Marxist, is under no nominal compulsion to achieve consistency" (46). But if that is the case, then the New Historicism must either come to look very much like the old historicism, in the sense of liberal historiography and literary history, or else it must, through adopting Foucault's genealogical procedures and philosophical nominalism, reject historicism altogether.[5] The New Historicism seeks to evade this theoretical problem in part by stressing the contingent in history, and therefore the very impossibility of systematizing it.

Cut loose from its moorings in some sense both of mimetic representation and of historical causality, the ship of the New Historicism drifts anywhere and everywhere, from anecdote to anecdote. Indeed, in place of lost metanarratives, the New Historicism's favored unit of narration is the decentered and presumably decentering anecdote (see Fineman). But the move from metanarratives to anecdotes solves nothing, because most of the same epistemological claims are at stake in both micro and macro forms of narration. Are they rooted in documentable evidence? What do they explain (what do they represent)? What explains them (why does the New Historicist choose to retell them)? And so forth. Arguments around representation are 
too familiar to rehearse here (but see Thomas, The New Historicism, 3-23). In relation to causality, however, Frank Lentricchia notes that, for there to be "historicism" at all, there must be some "principle of causality." He quotes Raymond Williams: "'A Marxism without some concept of determination is in effect worthless. A Marxism with many of the concepts of determination it now has is quite radically disabled.'" Lentricchia then writes: "Substitute historicism for Marxism and perhaps Stephen Greenblatt for Raymond Williams, and you have a description of the theoretical quandary within which some recent historically minded critics, with strong and problematical relations to Michel Foucault, and who tend to specialize in the English Renaissance, now find themselves" (Lentricchia 232).

Greenblatt's recent efforts to solve this "theoretical quandary" are, I think, both fascinating and unsatisfactory. The final two essays in Learning to Curse are as close to programmatic statements as he has yet written, but the first -- "Towards a Poetics of Culture" -- involves the rejection of both Marxist and poststructuralist theory as "eschatological," "utopian," or teleological in the bad old historicist sense. Lumping both Jameson's Marxism and Lyotard's poststructuralism under the unifying term "theory," Greenblatt accuses both of an "effacement of contradiction [which] is not the consequence of an accidental lapse but rather the logical outcome of theory's search for the obstacle that blocks the realization of its eschatological vision" (151).

But how is the "cultural poetics" Greenblatt would substitute for an "eschatological" Marxism and an equally eschatological poststructuralism an improvement? By implication, at least, cultural poetics would recognize the complexity or contradictoriness of capitalism as a world-historical process. Capitalism must be viewed, says Greenblatt, "not as a unitary demonic principle, but as a complex historical movement in a world without paradisal origins or chiliastic expections..." (151). In particular, in understanding the relationship between art and society, "complexity" must be an operative word, and in Greenblatt's essays the nature of that complexity is conveyed especially by quasi-economic terms such as "negotiation" and "circulation": "the work of art is the product of a negotiation between a creator or class of creators....and the institutions and practices of society. In order to achieve the negotiation, artists need to create a currency that is valid for a meaningful, mutually profitable exchange" (Learning 158). Greenblatt does not privilege the economic as final cause or outer limit, as in all variants of the Marxist base-superstructure paradigm, but rather treats it merely as the source of metaphors by which "exchanges" take place between a society's institutions and its artistic creators. These exchanges can be described on a case-by-case (anecdotal) basis, like Clifford Geertz's "thick description," and they can also be ascribed to the vast and vague set of economic developments and processes Greenblatt is still willing to call "capitalism" from the Renaissance forward, but they cannot be understood more systematically, as leading somewhere -- as the inexorable, world-unifying or -massifying march of economic and cultural modernization (and now postmodernism). 
A similar rejection of "theory" occurs in a different way in the last essay in Learning to Curse, "Resonance and Wonder." Here Greenblatt cites one of the definitions of "historicism" given by the American Heritage Dictionary: "The belief that processes are at work in history that man can do little to alter." Greenblatt responds: "New historicism, by contrast, eschews the use of the term 'man'; interest lies not in the abstract universal but in particular, contingent cases, the selves fashioned and acting according to the generative rules and conflicts of a given culture. And these selves, conditioned by the expectations of their class, gender, religion, race and national identity, are constantly effecting changes in the course of history" (164). That is to say, individuals may be "conditioned" by circumstances, but they have just as much to do with the making of the circumstances as viceversa. This tautological proposition leads Greenblatt next to assert "the new historicism's insistence on the pervasiveness of agency" (165). The idea here appears to be that, everywhere you look in history, there are people -- selves or individual "agents" -- doing things that affect the course of history. This idea in turn seems to be a variant of Foucault's famous proposition that "power breeds resistance," which means, of course, that there is "power" (hence, "agency") everywhere in society -- it's just that some "agents" have more of it than others. According to Althusser, for instance, an Ideological State Apparatus is an "agency" for self-fashioning that the selves fashioned have little or no control over. But Greenblatt's agents seem to be the selves or unit-individuals that make up the stock and trade of American individualism.

In a single loop, Greenblatt maintains contact with one of his power-sources -- Foucault -- while also giving expression to what Thomas calls the New Historicism's "unacknowledged link to American progressivism" (Thomas in Veeser, 197).[6] The New Historicism, according to Thomas, takes its place alongside other manifestations of neo-pragmatism in the U.S., and thereby "reaffirms the liberal tradition of American progressivism and its sense of temporality" (197), despite its challenges to "narratives of progressive emergence." It thus also reaffirms that tradition's sense of individual agency -- exactly the antithesis of Foucault's or Althusser's position with regard to the pervasiveness, at least in modern and now postmodern social formations, of deindividualized "power" --"discipline," the tyranny of "the Norm," etc. Rather than echoing Foucault's insistence upon the impending dissolution of that modern abstraction, "man," the New Historicism resuscitates that humanist abstraction through "self-fashioning."

In contrast, Cultural Studies maintains a more radical but nonetheless traditional emphasis on collective agency, which often takes the form of an appraisal of the potential for political resistance in various marginalized groups and cultural phenomena. Of course the search for resistance is a much-diminished version of the traditional Marxist goal of revolution. As a derivative of British democratic socialism, Cultural Studies no doubt remains consonant with earlier forms of Marxism, but, as Young suggests, 
may for that very reason fit less comfortably than the New Historicism does with poststructuralism.

Nevertheless, Young isn't the only critic who has suggested that Cultural Studies involves a sort of tame or watered down Marxism. Following Dick Hebdige's Subculture, some practitioners of Cultural Studies have been prone to discover and celebrate moments of "resistance" or even "subversion" in mass cultural forms (rock music, television, etc.) without Hebdige's ironic awareness that "power breeds resistance" which it is the very purpose or function of power to contain. So Judith Williamson complains about "left-wing academics [who] are busy picking out strands of 'subversion' in every piece of pop culture from Street Style to Soap Opera" (14; see also Morris).

The discovery of "critical and resistant elements" in the production and consumption of mass culture is analogous to Greenblatt's discovery of "agency" everywhere. Where before there appeared to be just domination, the ideological impositions of what Adorno and Horkheimer called the "culture industry," suddenly -- in the work of John Fiske, Iain Chambers, and others -- there appear to be complex negotiations over meanings and values going on between producers and consumers, or between the managers of the culture industries and their mass audiences. "The masses" of powerless, robotized "subjects" feared by Adorno and Horkheimer and anatomized by Althusser turn out to be everyday gals and guys pretty much just like you and me. Hey, we don't own corporations, but we know what we like in the way of tv shows, movies, and music, and we make our own sense of these mass cultural forms when we consume them. This is the meaning of those forms: we, the people, confer meaning and value on the products of the culture industries.

From this position it is just a short declension into "the Department of American Environments" (a.k.a. the Popular Culture Department) in Don DeLillo's White Noise. The narrator, Jack Gladney, who has himself founded "Hitler Studies" at the College on the Hill, describes his American Environments colleagues as

New York emigres, smart, thuggish, movie-mad, trivia-crazed. They are here to decipher the natural language of the culture, to make a formal method of the shiny pleasures they'd known in their Europe-shadowed childhoods -- an Aristotelianism of bubble gum wrappers and detergent jingles. (9)

Murray Siskind, a new arrival, who would like to emulate Jack by founding a department of "Elvis Studies," confesses to Jack that he doubts the legitimacy of the "popular culture" work of some of his colleagues: "'I 
understand the music, I understand the movies, '" Murray says; "'I even see how comic books can tell us things. But there are full professors in this place who read nothing but cereal boxes.'" Jack responds: "'It's the only avant-garde we've got'" (10).

This is, of course, parody rather than fair criticism of the analyses of mass media effects and audiences undertaken by Fiske, Chambers, and others. For one thing, social class does not disappear as a problematic in Fiske and Chambers as it does in much empiricist and functionalist American media research. But it is nevertheless true that, as in much western Marxist and now post-Marxist work, class is no longer the dominant or even clearly the main analytical category. Thus in Television Culture, Fiske writes that his pluralization of the term "audiences" at least "recognizes that we are not a homogeneous society, but that our social system is crisscrossed by axes of class, gender, race, age, nationality, region, politics, religion, and so on..." (17). Fiske thus recognizes the complexity of social processes under capitalist conditions much as Greenblatt does, though the risk of doing so lies in failing to explain that complexity and relying instead on something like (mere) thick description. Recognizing the complexity of social and ideological processes in capitalist societies, and at the same time, because of their affirmative, often appreciative stance toward the products of the culture industries as well as toward the audiences targeted by those industries, Fiske and Chambers also arrive at something close to Greenblatt's pragmatic liberalism.

Though Fiske and Chambers aren't its only representatives, their work shows how Cultural Studies also loops back toward a populist individualism that, whether in the British or the American setting, is only tangentially related to Marxism. Here, for instance, is Fiske writing about Gramsci's model of hegemony:

This definition of culture as a constant site of struggle between those with and those without power underpins the most interesting current work in cultural studies. Earlier work in the tradition tended to show how the dominant ideology reproduced itself invisibly and inevitably in the forms of popular television. [Stuart] Hall's influential essay, "Decoding and Encoding" is often seen as a turning point in British cultural studies, for it opened up the idea that television programs [and other forms of culture] do not have a single meaning, but are relatively open texts, capable of being read in different ways by different people. (260)

From this position, however, as Fiske well knows, the temptation of the Culturalist is to forego the analysis of differential "power" -- how the "struggle" proceeds -- for the bland assertion that everyone takes away from popular culture the meanings she or he wants, so that in the mere 
recognition of difference all social divisions appear miraculously healed. Indeed, continuing his account of Hall's "Encoding and Decoding," Fiske arrives at a word that once again connects Cultural Studies with the New Historicism: "Reading or viewing television, then, becomes a process of negotiation between the viewer and the text. Use of the word 'negotiation' is significant..." (260). The danger here, however, is not so much the New Historicist one of letting metaphors like "negotiation," "exchange," and "circulation" do the work of hard economic and social class analysis; rather, it is the suggestion that the viewers of television shows (e.g.) have as "active" a role to play in the "negotiation" or social construction of meanings from those shows as their producers. Where has the initial sense of unequal power relations in Fiske's statement gone? Consumers are never "active" in the same way as producers, nor can workers be "active" -- or even "negotiate" on equal terms -- with owners and capitalists. Fiske borrows some of his terminology from Michel de Certeau's Practice of Everyday Life, so he is aware that, for de Certeau, the "poacher" or "consumer" of meanings always operates from a position of weakness -- she may have "tactics" of resistance at her disposal, but not the grand "strategies" that are the preserve of the media managers.

Insofar as Cultural Studies has recently tended to emphasize consumption over production -- or in other words, to pay attention to the ways audiences construct meanings rather than to the ways the culture industries do so -there has been an imbalance. Older or more traditional forms of economic and ownership analysis need to be recalled - -- for example, Herbert I.

Schiller's The Mind Managers or Ben Bagdikian's The Media Monopoly. It strikes me as symptomatic of the current overemphasis in Cultural Studies on audience participation (again, compare "agency" in the New Historicism) that, in Television Culture, Fiske does not cite either Schiller or Bagdikian. Moreover, following the 1984 translation of Pierre Bourdieu's magisterial Distinction: A Social Critique of the Judgment of Taste, it is hard to see how there could be any doubt about the centrality of class to all questions about hierarchy, power, and esthetic judgment in all modern cultures and societies. Yet "class," especially in U.S. discourse, is almost always the first item to get elided in discussions of patterns of mass consumption and mass culture. In many situations today in the U.S., it seems to make more sense to talk about the homeless than about the proletariat; Britain at least continues to have a Labor Party.

According to Graeme Turner: "Popular culture is a site where the construction of everyday life may be examined. The point of doing this is not only academic...it is also political, to examine the power relations that constitute...everyday life and thus to reveal the configuration of interests its construction serves" (5-6; see also Easthope, and Grossberg et al.). If "subjectivity" is understood as a near-synonym for the individual's experience of the ordinary, then obviously the analysis of everyday life -- as in the work of Bourdieu and de Certeau -- is also identical to the analysis of the social construction of "the subject." Further, "popular" or "mass culture" 
is today more than just any old "site where the construction of everyday life may be examined." If, indeed, as Andreas Huyssen, Jean Baudrillard, and others have contended, postmodernity is characterized by the complete triumph of mass over all other forms of culture, then the postmodern signifying systems within which our individual "subjectivities" are forged are nothing more nor less than what Turner blandly calls "popular culture."

Just because high may be collapsing into mass culture, and just because the old, Marxist base/superstructure paradigm may be defunct, while forms of poststructuralism have arisen that treat all social phenomena as language, text or simulation, does not mean that social conflict has vanished along with the Soviet Union. A starting point for both the New Historicism and Cultural Studies must continue to be recognition of the differential power relations in history and society, and also among individuals, some of whom have far more "agency" than others: who dominates, who is dominated -- the old Hegelian Master and Slave paradigm -- this doesn't vanish as the central issue, even though the "economic mode of production" or "class conflict" can no longer be invoked as the exclusive motor of history, nor because we have now arrived at our postmodern senses and realize that "there is nothing outside the text."

Well, perhaps, there is nothing outside the yellow submarine of textuality or of culture but the ocean. But we can see the ocean through the portholes, we can analyze it, and we would be foolish not to: one name for it is material causation. Poststructuralism tends to severe the chord that ties the balloon of language, discourse, or culture to what Marx called "the real foundations." Those real foundations aren't some mysterious, inaccessible reality -- beyond the grasp of language to summon or name. On the contrary, discourse at least implicitly names its real foundations in every utterance, in every cultural form. Television shows, for example, do not just emanate from the airwaves as free-floating "texts" or "simulations." They have institutional, technological, and economic forces underlying them that are, in fact, much more than static "foundations" -- that produce them and their patterns of representation far more actively than, I believe, their audiences can be said to bestow meanings upon them.

On the other hand, as Dick Hebdige notes toward the end of Hiding in the Light, merely negative, merely intellectual critiques of the power relations in everyday life and the formation of our (and our students') subjectivities may not be sufficient, even when reinfused (as I am recommending) by a strong dose of materialism. Hebdige advocates a redefinition of "the function(s) of critique" that would involve concentrating "on the problematic of affect...." This move would constitute "a break with those forms of (interpretive, functionalist, (post)structuralist) cultural critique which are bound into the problematic of meaning. It involves a shift away from semiotics to pragmatics, from the analysis of the putative relations between cultural 
practices and social formations, between 'texts' and 'readers' towards a critical engagement with those processes through which libidinal and 'information' flows are organised..." (223). Maybe. But I would still contend that any version of a "politics of desire" such as Hebdige is advocating will simply spin off into celebrations of whatever happens to be desired (whatever produces the appropriate "affect") unless it continues to be rigorously theorized through older forms of critique, including those aspects of Marxism that are still useful for understanding "ideologies and ideological state apparatuses."

What, then, of the future of Cultural Studies and the New Historicism in higher education? My answer is, quite simply, that they seem to be the future -- or in other words, that they provide at least the beginnings of answers to the question, "What comes after poststructuralism?" Other, related forms of research and teaching are moving in related directions, for which "culture" seems now to be the vague sign -- Women's Studies, AfricanAmerican Studies, postcolonial literature courses and programs, multiculturalism. All these forms of academic work/political practice are responses to the widely acknowledged crisis in the humanities and social sciences (about which, see my Crusoe's Footprints 1-33). All of them move in the direction of a greater democratization of higher education, because the "decentering" of knowledges and of "the subject" by poststructuralisms means not just crisis in the negative sense, but an opening up of new possibilities. Above all, both the New Historicism and Cultural Studies make way for new voices -- for the voices of "others" previously exluded, for example, from academic canons and contexts -- and from roles of power in the organization of western universities and societies. The political goals of both the New Historicism and Cultural Studies are, in the words of Edward Said, "noncoercive knowledge produced in the interests of human freedom" (29). And as Hebdige eloquently writes: "There are many good things to be grown in the autumn of the patriarch, many good things to be found in the ruins, in the collapse of the older explanatory systems, in the splintering of the masterly overview and the totalising aspiration" (Hiding 225). Cultural Studies and the New Historicism are, I believe, among those "good things."

\section{Patrick Brantlinger}

\section{Department of English}

\section{University of Indiana}

Bloomington, IN, 47405 U.S.A. 


\section{WORKS CITED}

Bagdikian, Ben H., The Media Monopoloy (Boston: Beacon Press, 1983).

Baudrillard, Jean, Simulations (New York: Semiotext(e), 1983.

Bennington, Geoffrey, "Postal Politics and the Institution of the Nation," in Homi K. Bhabha, ed., Nation and Narration (London and New York: Routledge, 1990), 121-137.

Bourdieu, Pierre, Distinction: A Social Critique of the Judgment of Taste (Cambridge, MA: Harvard University Press, 1984).

Brantlinger, Patrick, Crusoe's Footprints: Cultural Studies in Britain and America (New York and London: Routledge, 1990).

Certeau, Michel de, The Practice of Everyday Life (Berkeley: University of California Press, 1984).

Chambers, Iain, Popular Culture: The Metropolitan Experience (London and New York: Methuen, 1986).

DeLillo, Don, White Noise (New York: Penguin Books, 1986).

Dollimore, Jonathan, and Alan Sinfield, eds., Political Shakespeare: New Essays on Cultural Materialism (Ithaca: Cornell University Press, 1985).

Easthope, Anthony, Literary into Cultural Studies (London: Routledge, 1991).

Fineman, Joel, "The History of the Anecdote: Fiction and Fiction," in Veeser, The New Historicism, 49-76.

Fiske, John, "British Cultural Studies and Television," in Robert C. Allen, ed., Channels of Discourse: Television and Contemporary Criticism (Chapel Hill: University of North Carolina Press, 1987).

Fiske, John, Television Culture (New York and London: Methuen, 1987).

Gallagher, Catherine, "Marxism and the New Historicism," in Veeser, The New Historicism, 37-48.

Greenblatt, Stephen J., Learning to Curse: Essays in Early Modern Culture (New York and London: Routledge, 1990).

Greenblatt, Stephen J., Marvelous Possessions: The Wonder of the New World (Chicago: University of Chicago Press, 1991). 
Grossberg, Lawrence, Cary Nelson, and Paula Treichler, eds., Cultural Studies (New York and London: Routledge, 1992).

Hebdige, Dick, Hiding in the Light: On Images and Things (London and New York: Routledge, 1988).

Hebdige, Dick, Subculture: The Meaning of Style (London: Methuen, 1979).

Huyssen, Andreas, After the Great Divide: Modernism, Mass Culture, Postmodernism (Bloomington: Indiana University Press, 1986).

Jameson, Fredric, Postmodernism: or, The Cultural Logic of Late Capitalism (Durham: Duke University Press, 1991).

Johnson, Richard, "What Is Cultural Studies Anyway?" Social Text 6:1 (1987), 38-80.

Lentricchia, Frank, "Foucault's Legacy: A New Historicism?" in Veeser, The New Historicism, 231-242.

Morris, Meaghan, "Banality in Cultural Studies," Discourse 10:2 (Spring/ Summer, 1988), 3-29.

Said, Edward, The World, the Text, and the Critic (Cambridge, MA: Harvard University Press, 1983).

Schiller, Herbert I., The Mind Managers (Boston: Beacon Press, 1973).

Thomas, Brook, "The New Historicism and Other Old-Fashioned Topics," in Veeser, The New Historicism, 182-203.

Thomas, Brook, The New Historicism and Other Old-Fashioned Topics (Princeton: Princeton University Press, 1991).

Turner, Graeme, British Cultural Studies: An Introduction (Boston: Unwin Hyman, 1990).

Veeser, H. Aram, ed., The New Historicism (New York and London: Routledge, 1989).

Williamson, Judith, "The Problems of Being Popular," New Socialist (September, 1986), 14-15.

Young, Robert, White Mythologies: Writing History and the West (London and New York: Routledge, 1990).

[1]A longer version of this essay is forthcoming in Isaiah Smithson, ed., English Studies/Cultural Studies, Southern Illinois University Press. I am grateful to Prof. Smithson and to SIU Press for permission to publish this version.

[2]On the "postal politics" of poststructuralism and of Derridean postcards, see Bennington. 
[3]For a related comparison, see Easthope, 119-123.

[4]Greenblatt may be more idiosyncratic than paradigmatic, but he is widely viewed as having founded or invented New Historicism. Some of the foibles or weaknesses I attribute to him, and therefore to the New Historicism, may be less in evidence among other "cultural historians" who are more or less connected to the New Historicism -- Natalie Zemon Davis, Lynn Hunt, and Thomas Laqueur, among others.

[5]Foucault offers a brilliant, charismatic, but ultimately contradictory model for reconstructing the past. Works like Discipline and Punish and The History of Sexuality are, in a sense, histories without history: "genealogies" which do not purport to reconstruct the past wie es eigentlich gewesen, but rather analyze texts which exist only in the present. This is not to say that the old historicism that Foucault subverts -- the historicism that, following Leopold von Ranke, sought to reconstruct the past "as it actually happened" -- is less contradictory than Foulcauldian genealogy: just the opposite. But histories influenced by Foucault are narratives woven out of present discourses that pertain to an irretrievable, ultimately unknowable past - -narratives motivated by the historian's "will to knowledge" rather than grounded in any scientific or verifiable methodology that can produce "the truth."

[6]A version of the essay reappears in Thomas's The New Historicism and Other Old Subjects, the fullest account (and critique) to date of the New Historicism. 